\title{
Allergic diseases: the price of civilisational progress
}

\author{
Krzysztof Rutkowski ${ }^{1}$, Paweł Sowa ${ }^{2}$, Joanna Rutkowska-Talipska ${ }^{3}$, Stanisław Sulkowski ${ }^{4}$, Ryszard Rutkowski ${ }^{5}$
}

\author{
${ }^{1}$ Department of Allergy, Cambridge University Hospital, Cambridge, United Kingdom \\ Head of Department: Dr P.W. Ewan FRCP, FRCPath \\ ${ }^{2}$ Department of Public Health, Medical University of Bialystok, Poland \\ Head of Department: Prof. Andrzej Szpak MD, PhD \\ ${ }^{3}$ Department of Rehabilitation, Medical University of Bialystok, Poland \\ Head of Department: Prof. Anna Kuryliszyn-Moskal MD, PhD \\ ${ }^{4}$ Department of Pathomorphology, Medical University of Bialystok, Poland \\ Head of Department: Prof. Andrzej Kemona MD, PhD \\ ${ }^{5}$ Department of Respiratory Diagnostic and Bronchoscopy, Medical University of Bialystok, Poland \\ Head of Department: Prof. Zenon Siergiejko MD, PhD
}

Postep Derm Alergol 2014; XXXI, 2: 77-83

DOI: $10.5114 /$ pdia.2014.40936

\begin{abstract}
Atopic disorders are a major global health problem. The prevalence of asthma, allergic rhinitis and atopic dermatitis has been increasing over the last four decades, both in the industrialized and developing countries. It seems to be related to changes in the social structure, increasing industrialization, pollution and dietary changes. Many hypotheses link the allergy epidemic to stringent hygiene, dominance of a westernized lifestyle and an accelerated pace of life. Dietary antioxidants, lipids, sodium, vitamin D seem also to be implicated. We endeavour to review the most relevant theories with a special emphasis on the hygiene, antioxidative, lipid and air pollution hypotheses. It is however important to note that none of them explains all the aspects of unprecedented rise in the prevalence of allergic disorders. A complex interplay between host's immune response, invading pathogens, diversity of environmental factors and genetic background seems to be of a particular importance. Current allergy epidemic is multifactorial and basic and epidemiologic studies are warranted to further our understanding of this phenomenon.
\end{abstract}

Key words: allergy, environment, epidemic, genes, hypothesis, nutrition.

\section{Introduction}

Atopic disorders represent a global health problem. A number of studies have demonstrated an increase in the prevalence of asthma, allergic rhinitis (AR) and atopic dermatitis (AD) over the last four decades, particularly in children. This increase has been observed in both industrialized and developing countries [1-6]. World Health Organization estimates that 400 million people suffer from AR and 300 million from asthma. By 2025, additional 100 million will be affected by asthma [1, 4, 5]. This sharp increase in asthma and other allergic diseases between early 1960 s and late 1980 s is perceived to be a consequence of an intense migration from rural to urban regions, from poor, developing countries to rich, but heavily industrialized regions of Europe, Asia and Americas. Migration from the countryside to cities, from economically backward to economically developed countries has exposed migrants to a new set of harmful pollutants and allergens and changed their housing conditions, diet and access to medical services [1, 2, 4, 5, 7].

A number of genetic and environmental risk factors (Table 1) may contribute to the rise in asthma, $A R$ and $A D$ morbidity and modify their clinical course. Genetic factors are undoubtedly important in the development of allergy. However it seems improbable that genetic variants associated with atopy would trigger the disease without the influence of various environmental factors [4, 5, 8-10]. Moreover, the role of genomic transformation is rather limited, because the increase in allergy has happened over a relatively short period of time. Hence, many epidemiologic studies point to a potential role of various environmental factors in the increase of atopic diseases [9, 11, 12].

Many hypotheses link the allergy epidemic to stringent hygiene in early life, replacement of a traditional way of living by a westernized lifestyle and an accelerated pace of life $[1,2,4,5,7,13]$. There are epidemiological and experimental data to substantiate various hypotheses:

Address for correspondence: Krzysztof Rutkowski MD, Allergy Department, Clinic 2a, Cambridge University Hospitals NHS Foundation Trust, Cambridge CB2 0QQ, United Kingdom, phone: +44 1223589 977, e-mail: krzysztof.rutkowski@addenbrookes.nhs.uk Received: 24.09.2013, accepted: 28.09.2013. 
Table 1. Factors influencing the development and expression of allergic diseases $[4,5,11,18]$

\begin{tabular}{l} 
Host factors \\
\hline Genetics: \\
- genes predisposing to atopy, e.g. FCR1A (Fc fragment of IgE, high affinity receptor for alpha subunit) \\
- genes predisposing to airway hyperreactivity, e.g. DARC (Duffy antigen/receptor for chemokines) \\
- genes directly modulating responses to environmental exposures, e.g. CD14, Toll-like receptor 4 polymorphism \\
- genes determining the tissue response to chronic inflammation, e.g. ADAM33 (A disintegrin and metalloproteinase domain- \\
containing protein 33), PDE4D (phosphodiesterase 4D) \\
\hline Obesity: body mass index $(\mathrm{BMI})>30 \mathrm{~kg} / \mathrm{m}^{2}$
\end{tabular}

Obesity: body mass index $(\mathrm{BMI})>30 \mathrm{~kg} / \mathrm{m}^{2}$

Male sex in childhood

Inhaled environmental factors

Allergens:
- Indoor, e.g. mites, animal dander (dogs, cats, mice), cockroaches, fungi, moulds, yeasts
- Outdoor, e.g. pollens, fungal spores

Outdoor/indoor air pollutants: $\mathrm{CO}$ (carbon monoxide), $\mathrm{CO}_{2}$ (carbon dioxide), $\mathrm{NO}$ (nitrogen dioxide), $\mathrm{SO}_{2}$ (sulphur dioxide), PAHs (polycyclic aromatic hydrocarbons), $\mathrm{O}_{3}$ (ozone), particulate matter (PM)

Infectious agents (predominately viral)

Tobacco smoke:

passive smoking: maternal prenatal smoking, postnatal environmental tobacco smoke exposure; active smoking

Occupational sensitizers, e.g. flour, soybean dust, wood dust, grain dust, formaldehyde

Non-inhaled environmental factors

Foods, e.g. peanuts, tree nuts, wheat, soy, egg

Ticks, Hymenoptera

Occupational sensitizers, e.g. nickel, platinum, vanadium salts

Diet

- original hygiene hypothesis: improved hygiene in early life, reduction of family size and number of siblings [4, $5,14,15]$

- extended hygiene hypothesis: replacement of traditional anthroposophic way of living, combining elements of conventional medicine (restrictive use of antibiotics, antipyretics and vaccination) with homeopathy and naturopathy (biodynamic diet) by modern lifestyle and new medical recommendations [6, 13, 16, 17]; reduced early exposure to infectious and microbial agents [9, 17-24]; shorter period of breast feeding with unfavourable changes in the gut flora [2, 11, 25, 26],

- first dietary antioxidant hypothesis: antioxidant-depleted Western diet [1, 3, 11, 27-29],

- second dietary antioxidant hypothesis: increased availability of antioxidant-rich ("healthy") foods, especially dietary supplements such as vitamins, food preservatives or colorants and traditional Chinese or Vietnamese herbal medicine extracts [1, 30, 31],

- dietary lipid hypothesis: decreased consumption of saturated animal fat (butter, lard) and oily fish containing long chain n-3 polyunsaturated fatty acids (PUFA), increased intake of margarine, vegetable oils and fast food meals rich in n-6-PUFAs [1, 11, 27, 32, 33],

- dietary sodium hypothesis: sodium-rich Western diet [11, 24, 34],

- vitamin D deficiency hypothesis: decreased vitamin D synthesis in skin due to environmental, behavioural and intrinsic factors, in particular reduced exposure to solar radiation because of urban living, indoor occupation, pollution, skin coverage and excessive use of sunscreen for skin cancer prevention [1, 35, 36],

- vitamin D supplementation hypothesis: delayed side effect of early rickets prophylaxis with vitamin D supplements or excessive maternal concentration of 25(OH)-vitamin D in pregnancy [1, 37-40],

- maternal diet hypothesis: low maternal vitamin D, antioxidants and 3- $\omega$-PUFAs intake in pregnancy [1, 3, 11, 25],

- parental smoking during pregnancy and postnatal exposure to environmental tobacco smoke [2, 5, 29, 41],

- migration from rural regions to heavily industrialised areas, especially highly polluted by diesel exhaust and other gaseous particulate pollutants [4, 5, 42-44], 
- living in poor urban communities with an increased exposure to house dust mites, cockroaches and other indoor allergens [5, 41, 45-48],

- psychosocial stress hypothesis: accelerated rhythm of modern life, psychosocial violence or trauma [5, 7 , 48-51].

Replacement of traditional, fermented and antioxidant-rich diet by modern cuisine, limited natural early childhood exposure to microbes and excessive exposure to outdoor pollution in the industrialised regions seem to be the most important factors in the epidemiology of asthma, AR and $\operatorname{AD}[1,3,5,17,19,42,43]$.

\section{Role of genetic transformations}

Mutation in the Duffy antigen receptor for chemokines (DARC), originally selected to increase natural resistance against Plasmodium vivax in the sub-Saharan and West African populations and the descendants of African-Caribbeans, African-Americans, African-Europeans, African-Brazilians and African-Columbians is accompanied by an increased risk of allergic diseases. The point mutation in the consensus binding site of the erythroid transcription factor GATA1 in the DARC promoter (T-46C) selectively decreases DARC expression on red blood cells conferring resistance of DARC-negative erythrocytes to Plasmodium vivax. Unfortunately, DARC also binds with high affinity to the CXC and CC chemokines which favours allergic inflammation, high total lgE levels and atopy in these minorities [18, 52].

Endotoxin, a soluble lipopolysaccharide (LPS) fragment of the outer membrane of Gram-negative bacteria binds to LPS receptor (CD14) on antigen presenting cells (APC), particularly monocytes. It stimulates interleukin (IL-) 12 production, which promotes Th1 response and generates neutrophil-activating IL-8. Thus, exposure to endotoxins, abundantly present in rural and farming communities, exerts protective action against Th2 response and diminishes the risk of allergic diathesis in infancy [10, 22, 53]. Single nucleotide polymorphism in the $5^{\text {th }}$ genomic region of CD14 (CD14/-159) is an important variant in relation to asthma and allergy. CD14 (CD14/ -159) T allele homozygotes are in fact less prone to allergic response because of a higher expression of CD14 and higher sensitivity to environmental microbe exposure. In an environment with low endotoxin levels, this allele increases CD14 receptor availability and renders children more sensitive to the purported protective influence of the endotoxin. However, at a higher level of the endotoxin, the T allele has the opposite effect and does not protect against asthma and atopy [8].

\section{Hygiene hypothesis}

Genetic studies of CD14 and TLR4 polymorphism allow, at least in part, to understand the role of socioeco- nomic factors (family size, structure changes, rejection of anthroposophic lifestyle) in the increased prevalence of allergy $[8,13,14,18,53]$.

Since 1989, when Strachan coined the term "hygiene hypothesis" to explain the protection from hay fever among individuals with multiple older siblings, this hypothesis has evolved with respect to potential underlying immunological mechanisms and the type of infectious/ microbial stimuli $[14,15,18,22]$. Different epidemiological and experimental studies support Strachan's theory that limitation of the natural immune response to microbial components in early life increases Th2 clonal proliferation and enhances allergy [18, 21-23]. More recently, the hygiene hypothesis has been extended to include the concept of "gut flora". The PARSIFAL (Prevention of Allergy Risk Factors for Sensitization in Children Related to Farming and Anthroposophic Lifestyle) and GABRIELA (Multidisciplinary Study to Identify the Genetic and Environmental Causes of Asthma in European Community [Gabriel] Advanced Study) multi-centre studies have confirmed that growing up on a farm, exposure to livestock and consumption of unheated farm milk confers significant protection against the atopy [10, 17-19, 54, 55]. Exposure to various infectious agents or their products however may have bidirectional effects on allergy and asthma, and relates to the timing of the exposure. Prenatal (maternal) or early life contact with microbes of cattle sheds, haylofts and farm animals prevents allergy while later in life the same microbial exposure to livestock or poultry may exacerbate existing atopic disorders [20, 24].

The "hygiene" hypothesis is unquestionably scientifically relevant, but it does not fully explain the allergy epidemic. Why do helminthic infections, which promote a Th2 immune response, reduce the prevalence of allergic disease $[17,18,56]$ ? What is the link between obesity and asthma? Why is the prevalence of asthma high in poor urban environments where children who have asthma are also at risk of infections $[18,22,53]$ ?

Therefore, in the past 20 years new hypotheses have focused on the negative changes in human diet and noxious air pollution as environmental factors responsible potentially for an increase in allergic disorders in the developed countries [1, 3, 25, 42, 43].

\section{Dietary antioxidative hypothesis}

A dietary antioxidant deficiency impairs natural antioxidant defence mechanisms, increases susceptibility to the oxidative attack and allergy [3, 11, 28]. In 1994, Seaton et al. suggested that an increased prevalence of asthma and atopy in the United Kingdom was a consequence of declining intake of dietary antioxidants. Between 1961 and 1985, National Food Surveys revealed that the average weekly consumption of fresh fruits fell by $26 \%$ from $611 \mathrm{~g}$ to $451 \mathrm{~g}$ and green vegetables by $51 \%$ from $422 \mathrm{~g}$ to $204 \mathrm{~g}$. In the same period there was a re- 
duction in the consumption of fresh fish and red meat which are a source of essential antioxidants: selenium, zinc and copper [29].

Worldwide, an inadequate consumption of fresh fruits, green vegetables and potatoes - main sources of antioxidants such as vitamin C, vitamin E, vitamin A, $\beta$-carotene and selenium - has been associated not only with allergy but also lung function test results [57-61]. Winter consumption of vitamin C-rich citrus and kiwi fruits, 5-7 times per week, significantly protected 6-7-year-old children against wheeze and cough. This was evident even if fruits had been eaten 1-2 times per week only [62]. In turn, in healthy Californian school-age children, a low intake of fruits, vegetables and juices was associated with impaired lung functions. A low total vitamin $C$ and vitamin $E$ intake was associated with a deficit in forced expiratory volume in the $1^{\text {st }} \mathrm{S}\left(\mathrm{FEV}_{1}\right)$ and forced expiratory flow between $25 \%$ and $75 \%$ of forced vital capacity (FEF25-75\%). A low vitamin A intake was associated with lower FEF25-75 values in boys with asthma and healthy girls [63]. A similar tendency was observed in adult participants where low levels of plasma vitamin C and selenium were associated with low FEV 1 values [59]. Dietary supplementation with vitamins $\mathrm{E}$ and $\mathrm{C}$ benefited asthmatic adults exposed to ozone. Moreover, subjects given dietary antioxidants responded less severely to sulphur dioxide bronchial challenge [64].

Two recent systematic reviews and metanalyses confirmed this weakly positive effect of vitamin A, D, C, E, zinc, fruits, vegetables and the "Mediterranean diet" on asthma outcomes $[65,66]$. The evidence for a particular role of antioxidants in asthma and other allergic diseases however remains inconclusive and the association between diet and asthma is still far from clear $[1,67]$.

Table 2. Biological effects of diesel exhaust and diesel exhaust particles (DEP) $[42,67,71,73,76,77]$

\begin{tabular}{|c|c|}
\hline Model & Biological effects \\
\hline \multirow{4}{*}{$\begin{array}{l}\text { Human } \\
\text { studies }\end{array}$} & Diesel exhaust in healthy subjects \\
\hline & $\begin{array}{l}\uparrow \text { Airways inflammatory cells (neutrophils, B-, T- and mast cells); circulating neutrophils and platelets; histamine levels; } \\
\text { production of IL- } 6 \text { and CXC chemokines (IL- } 8 \text { and GRO- } \alpha \text { ); adhesion molecules ICAM-1 and VCAM-1; airway resistance } \\
\downarrow \text { macrophage function }\end{array}$ \\
\hline & Diesel exhaust in subjects with mild asthma \\
\hline & $\begin{array}{l}\text { 个 IgE production; Th2 cytokines (IL-4, 5, 6, } 10 \text { and 13); methacholine hyperresponsiveness and airway resistance; } \\
\text { sputum IL-6 levels; epithelial staining for IL-10 and VCAM-1 }\end{array}$ \\
\hline \multirow[t]{8}{*}{$\begin{array}{l}\text { Animal } \\
\text { studies }\end{array}$} & $\begin{array}{l}\uparrow \text { Airway inflammation with infiltration by alveolar macrophages, mast cells, neutrophils and eosinophils } \\
\uparrow \text { Allergen-induced airway inflammation (DEP as an adjuvant); proinflammatory cytokines IL-1 } \beta \text {, TNF- } \alpha, \text { MIP-1 } \alpha \text {; } \\
\text { hypertrophy of mucous cells and mucus hypersecretion; hyperplasia of alveolar type II epithelial cell, precipitation of } \\
\text { airway hyperreactivity }\end{array}$ \\
\hline & Bronchial and nasal epithelial and endothelial cells \\
\hline & $\begin{array}{l}\uparrow \text { Chemokines and cytokines: IL-6, 8, eotaxin, RANTES, GM-CSF; histamine } 1 \text { receptor, ICAM-1 and phase } 2 \text { enzymes } \\
\downarrow \text { Ciliary beat frequency }\end{array}$ \\
\hline & Eosinophils \\
\hline & 个Adhesion to nasal epithelial cells; degranulation \\
\hline & Mast cells \\
\hline & $\uparrow$ IgE-mediated histamine release and IL-4, 6 production \\
\hline & Basophils \\
\hline
\end{tabular}

Cultured
cells studies Histamine release in the absence of IgE; stimulation of IL-4 production

Peripheral blood mononuclear cells

$\uparrow$ Chemokines (IL-8, RANTES); synergy with allergens to increase IL-8, RANTES and TNF- $\alpha$ production

B cells

$\uparrow$ IgE production after IL-4 and anti-CD40 stimulation

Monocytes-macrophages

Modulation of cytokine production (e.g. inhibition of IL-12p40)

$\downarrow$ Prostaglandin E2 release

$\uparrow$ Expression of phase 2 enzymes

IL-interleukin, GRO- $\alpha$-growth-regulated oncogene- $\alpha$, ICAM-1-intercellular adhesion molecule 1, VCAM-1-vascular cell adhesion molecule 1, TNF- $\alpha$ - tumour necrosis factor- $\alpha$, MIP-1 $\alpha$ - macrophage inflammatory protein-1 $\alpha$, RANTES - regulated upon activation, normal T-cell expressed and secreted, GM-CSF-granulocyte-macrophage colony-stimulating factor 


\section{Lipid hypothesis}

Black and Sharpe questioned the antioxidative hypothesis in 1997 and proposed the lipid hypothesis. They noticed that in the developed countries in the second half of the $20^{\text {th }}$ century there was a fall in consumption of saturated fat (butter and lard) and increase in consumption of margarine and vegetable oils rich in n-6 polyunsaturated fat (PUFA), particularly linoleic acid. It stimulates prostaglandin (PG) E2, which inhibits interferon (INF-) $\gamma$, but not IL-4. This in turn promotes immunoglobulin (Ig) E production. In the United Kingdom, the rise in linoleic acid consumption preceded the increase in asthma by several years [3, 25, 32]. This negative tendency has since disseminated worldwide due to the popularity of fast food restaurants [27, 33]. The lipid theory is supported by many publications which suggest the an increased consumption of processed food rich in n-6 PUFAs instead of n-3 PUFA-rich oily fish (tuna, herring, mackerel, salmon, sardines, trout, tuna) and cod liver oil have contributed to a recent increase in asthma and atopy [1, 27, 32, 33]. Unfortunately, intervention studies have not found consistent results nor provided sufficient support for dietary supplementation with PUFAs [25, 67-70].

\section{Air pollution hypothesis}

The modern westernised diet, increased exposure to house dust mites and cockroaches, viral infections and other factors undoubtedly play a significant role in the aetiology of allergic diseases. Air pollution is a particularly important public health problem, as about $47 \%$ of the global population live in urbanized areas [42-44, 71]. Air pollution originates from natural, agricultural, mobile and industrial sources [72-74]. Atmospheric pollutants typically include ozone $\left(\mathrm{O}_{3}\right)$, sulphur $\left(\mathrm{SO}_{x}\right)$ and nitrogen oxides (NO), carbon monoxide (CO) and particulate matter (PM), generated by automobile traffic and industry [42-44, 72, 75]. In 1998, in Japan, almost $100 \%$ of particulate matter was contained in motor vehicles' diesel exhaust. Diesel engines are increasingly popular because of their superior energy efficiency and endurance. Modern mass transportation, especially in the US and Japan, is dominated by lorries, buses, trains and off-road equipment with a diesel engine [42-44, 76]. The incomplete combustion of fuel and diesel engine oil leads to formation of noxious substances like sulphur dioxide $\left(\mathrm{SO}_{2}\right)$, nitrogen oxides $\left(\mathrm{NO}, \mathrm{NO}_{2}\right)$, carbon monoxide (CO), benzene, transition metals, formaldehyde, hydrocarbons and diesel particulate matters (DEPs) [71, 72, 74, 77]. These highly reactive, ultrafine particles with an aerodynamic diameter $\leq 0.1 \mu \mathrm{m}$ constitute more than $80 \%$ of total DEPs $[42,43,71]$. Diesel exhaust particles, especially fine particulate matter $\leq 2.5$ microns $\left(\mathrm{PM}_{2.5}\right.$ ), enhance IgE-mediated aeroallergen sensitization and Th2 cytokine response and induce many immunological and clinical changes (Table 2).
Diesel exhausts induce oxidative stress, lead to nuclear translocation of the stress-related mitogen-activated protein kinases (MAPK): p38 and c-Jun N-terminal kinases (JNK); activation of nuclear factor- $\mathrm{B}(\mathrm{NF}-\kappa \mathrm{B})$ transcriptional factor and increased synthesis and release of pro-inflammatory cytokines and adhesion molecules [44, 71, 74, 75, 78]. Therefore, DEPs and diesel exhaust are considered to be responsible for the traffic-related increase in airway inflammation, allergy and asthma exacerbations [42-44, 72].

\section{Conclusions}

It is highly probable that all of these factors have contributed to the current allergy epidemic. None of them however is the basis for that simple formula that "fits it all together" [8]. There is a complex interplay between host's immune response, invading microorganism, variety and levels of environmental factors and genetic background [79]. Almost 40 years ago Gerrard et al. rightly pointed out that "atopic disease is the price paid by some members of the white community for their relative freedom from diseases due to viruses, bacteria, and helminths" [80]. Allergic pandemic of the second half of the $20^{\text {th }}$ century seems to be the price to pay for civilisational progress.

\section{Conflict of interest}

All authors declare no conflict of interest.

\section{References}

1. Allan K, Devereux G. Diet and asthma: nutrition implications from prevention to treatment. J Am Diet Assoc 2011; 111: 258-68.

2. Baena-Cagnani CE, Serra H, Teijero A, Croce JS. Prevention of allergy and asthma. Clin Exp All Rev 2003; 3: 51-7.

3. Devereux G. Allergic disease: Nutrition as a potential determinant of asthma. Proc Nutr Soc 2010; 69: 1-10.

4. Global Initiative for Asthma Management and Prevention, 2011, http://www.ginasthma.org/uploads/users/files/GINA Report2011 May4.pdf

5. Pawankar R, Canonica GW, Holgate ST, Lockey RF. WAO White Book on Allergy 2011-2012: WAO, 2011, Milwaukee, Wisconsin, USA 1-220, http://www.worldallergy.org/UserFiles/file/WAO-White-Book-on-Allergy_web.pdf

6. Kamer B, Pasowska R, Dółka E, et al. Prevalence of atopic dermatitis in infants during the first six months of life: authors' observations. Postep Derm Alergol 2013; 30: 277-81.

7. Mingomataj E. Changing World As Principal Reason For Atopy Rising Trend. The Internet Journal of Asthma, Allergy and Immunology 2007; 5; DOI: 10.5580/efO, http://www. ispub.com:80/journal/the-internet-journal-of-asthma-allergy-and-immunology/volume-5-number-2/changing-worldas-principal-reason-for-atopy-rising-trend.html

8. Martinez FD. Gene-environment interactions in asthma: with apologies to William of Ockham. Proc Am Thorac Soc 2007; 4: 26-31. 
9. Peden DB. Influences on the development of allergy and asthma. Toxicology 2002; 181-182: 323-8.

10. Smit LA, Siroux V, Bouzigon E, et al. Epidemiological Study on the Genetics and Environment of Asthma, Bronchial Hyperresponsiveness, and Atopy (EGEA) Cooperative Group. CD14 and toll-like receptor gene polymorphisms, country living, and asthma in adults. Am J Respir Crit Care Med 2009; 179: 363-8.

11. Tricon S, Willers S, Smit HA, et al. Nutrition and allergic disease. Clin Exp Allergy Rev 2006; 6: 117-88.

12. Nowak M, Szymańska A, Grewling Ł. Allergic risk zones of plane tree pollen (Platanus sp.) in Poznan. Postep Derm Alergol 2012; 29: 156-60.

13. Flöistrup H, Swartz J, Bergström A, et al. PARSIFAL Study Group. Allergic disease and sensitization in Steiner school children. J Allergy Clin Immunol 2006; 117: 59-66.

14. Strachan DP. Hay fever, hygiene, and household size. BMJ 1989; 299: 1259-60.

15. Strachan DP. Allergy and family size: a riddle worth solving. Clin Exp Allergy 1997; 27: 235-6.

16. Alfvén T, Braun-Fahrländer C, Brunekreef B, et al. PARSIFAL study group. Allergic diseases and atopic sensitization in children related to farming and anthroposophic lifestyle the PARSIFAL study. Allergy 2006; 61: 414-21.

17. Ege MJ, Mayer M, Normand AC, et al. GABRIELA Transregio 22 Study Group. Exposure to environmental microorganisms and childhood asthma. N Engl J Med 2011; 364: 701-9.

18. Barnes KC. Genetic studies of the etiology of asthma. Proc Am Thorac Soc 2011; 8: 143-8.

19. Lee SY, Kwon JW, Seo JH, et al. Prevalence of atopy and allergic diseases in Korean children: associations with a farming environment and rural lifestyle. Int Arch Allergy Immuno 2012; 158: 168-74.

20. Naleway AL. Asthma and atopy in rural children: is farming protective? Clin Med Res 2004; 2: 5-12.

21. Paunio M, Heibonen OP, Virtanen M, et al. Measles history and atopic diseases: a population-based cross-sectiona study. JAMA 2000; 283: 343-6.

22. Reed CE, Milton DK. Endotoxin-stimulated innate immunity: a contributing factor for asthma. J Allergy Clin Immunol 2001; 108: 157-66.

23. Shirakawa T, Enamoto T, Shimazu S, Hopkin JM. The inverse association between tuberculin responses and atopic disorder. Science 1997; 275: 77-9.

24. Vercelli D. Learning from discrepancies: CD14 polymorphisms, atopy and the endotoxin switch. Clin Exp Allergy 2003; 33: 153-5.

25. Kim JH, Ellwood PE, Asher MI. Diet and asthma: looking back, moving forward. Respir Res 2009; 10: 49.

26. Vael C, Desager K. The importance of the development of the intestinal microbiota in infancy. Curr Opin Pediatr 2009; 21: 794-800.

27. Nagel G, Weinmayr G, Kleiner A, et al. ISAAC Phase Two Study Group. Effect of diet on asthma and allergic sensitisation in the International Study on Allergies and Asthma in Childhood (ISAAC) Phase Two. Thorax 2010; 65: 516-22.

28. Riccioni G, Barbara M, Bucciarelli T, et al. Antioxidant vitamin supplementation in asthma. Ann Clin Lab Sci 2007; 37 96-101.

29. Seaton A, Godden DJ, Brown K. Increase in asthma: a more toxic environment or a more susceptible population? Thorax 1994; 49: 171-174
30. Murr C, Schroecksnadel K, Winkler C, et al. Antioxidants may increase the probability of developing allergic diseases and asthma. Med Hypotheses 2005; 64: 973-7.

31. Zaknun D, Schroecksnadel S, Kurz K, Fuchs D. Potential role of antioxidant food supplements, preservatives and colorants in the pathogenesis of allergy and asthma. Int Arch Allergy Immunol 2012; 157: 113-24.

32. Black PN, Sharpe S. Dietary fat and asthma: is there a connection? Eur Respir J 1997; 10: 6-12.

33. Wickens K, Barry D, Friezema A, et al. Fast foods - are they a risk factor for asthma? Allergy 2005; 60: 1537-41.

34. Burney P. A diet rich in sodium may potentiate asthma. Epidemiologic evidence for a new hypothesis. Chest 1987; 91: 143S-8S.

35. Bozzetto S, Carraro S, Giordano G, et al. Asthma, allergy and respiratory infections: the vitamin $\mathrm{D}$ hypothesis. Allergy 2012; 67: 10-7.

36. Litonjua AA, Weiss ST. Is vitamin D deficiency to blame for the asthma epidemic? J Allergy Clin Immunol 2007; 120: 1031-5.

37. Gale CR, Robinson SM, Harvey NC, et al. Princess Anne Hospital Study Group. Maternal vitamin D status during pregnancy and child outcomes. Eur J Clin Nutr 2008; 62: 68-77.

38. Wjst M, Dold S. Genes, factor X, and allergens: what causes allergic diseases? Allergy 1999; 54: 757-9.

39. Wjst M. The vitamin D slant on allergy. Pediatr Allergy Immunol 2006; 17: 477-83.

40. Szczawińska-Popłonyk A, Bręborowicz A. Vitamin D impact on immune functions: implications for preventive strategy of allergic disease? Postep Derm Alergol 2012, 29: 176-81.

41. Chen YC, Tsai CH, Lee YL. Early-life indoor environmental exposures increase the risk of childhood asthma. Int J Hyg Environ Health 2011; 215: 19-25.

42. Ghio AJ, Smith CB, Madden MC. Diesel exhaust particles and Airways inflammation. Curr Opin Pulm Med 2012; 18: 144-50.

43. Kim BJ, Hong SJ. Ambient air pollution and allergic diseases in children. Korean J Pedatr 2012; 55: 185-92.

44. Takizawa $\mathrm{H}$. Impact of air pollution on allergic diseases. Korean J Intern Med 2011; 26: 262-73.

45. Arruda LK, Vailes LD, Ferriani VP, et al. Cockroach allergens and asthma. J Allergy Clin Immunol 2001; 107: 419-28.

46. Żukiewicz-Sobczak WA. The role of fungi in allergic diseases. Postep Derm Alergol 2013; 30: 42-5.

47. Huss K, Adkinson NF Jr, Eggleston PA, et al. House dust mite and cockroach exposure are strong risk factors for positive allergy skin test responses in the Childhood Asthma Management Program. J Allergy Clin Immunol 2001; 107: 48-54.

48. Silvers SK, Lang DM. Asthma in African-Americans: what can we do about the higher rates of disease. Cleve Clin J Med 2012; 79: 193-201.

49. Tomita K, Hasegawa Y, Watanabe M, et al. The Totton-Ken Seibu earthquake and exacerbation of asthma in adults. J Med Invest 2005; 52: 80-4.

50. Ograczyk A, Malec J, Miniszewska J, Zalewska-Janowska A. Psychological aspects of atopic dermatitis and contact dermatitis: stress coping strategies and stigmatization. Postep Derm Alergol 2012; 29: 14-8.

51. Teresiak-Mikołajczak E, Czarnecka-Operacz M, Jenerowicz D, Silny W. Neurogenic markers of the inflammatory process in atopic dermatitis: relation to the severity and pruritus. Postep Derm Alergol 2013; 30: 286-92.

52. Vergara C, Tsai YJ, Grant AV, et al. Gene encoding Duffy antigen/receptor for chemokines is associated with asthma and 
IgE in three populations. Am J Respir Crit Care Med 2008; 178: 1017-22.

53. Herz U, Lacy P, Renz H, Erb K. The influence of infections on the development and severity of allergic disorders. Curr Opin Immunol 2000; 12: 632-40.

54. Loss G, Apprich S, Waser M, et al. GABRIELA study group. The protective effect of farm milk consumption on childhood asthma and atopy: the GABRIELA study. J Allergy Clin Immunol 2011; 128: 766-73.

55. Waser M, Michels KB, Bieli C, et al. PARSIFAL Study team. Inverse association of farm milk consumption with asthma and allergy in rural and suburban populations across Europe. Clin Exp Allergy 2007; 37: 661-70.

56. van den Biggelaar AH, van Ree R, Rodrigues LC, et al. Decreased atopy in children infected with Schistosoma haematobium: a role for parasite-induced interleukin-10. Lancet 2000; 356: 1723-7.

57. Casagrande SS, Wang Y, Anderson C, Gary TL. Have Americans increased their fruit and vegetable intake? The trends between 1988 and 2002. Am J Prev Med 2007; 32: 257-63.

58. Patel S, Murray CS, Woodcock A, et al. Dietary antioxidant intake, allergic sensitization and allergic diseases in young children. Allergy 2009; 64: 1766-72.

59. Pearson P, Britton J, McKeever T, et al. Lung function and blood levels of copper, selenium, vitamin C and vitamin E in the general population. Eur J Clin Nutr 2005; 59: 1043-8.

60. Ravindran RD, Vashist P, Gupta SK, et al. Prevalence and risk factors for vitamin $C$ deficiency in north and south India: a two centre population based study in people aged 60 years and over. PLoS One 2011; 6: e28588.

61. Rubin RN, Navon L, Cassano PA. Relationship of serum antioxidants to asthma prevalence in youth. Am J Respir Crit Care Med 2004; 169: 393-8.

62. Forastiere F, Pistelli R, Sestini P, et al. Consumption of fresh fruit rich in vitamin $C$ and wheezing symptoms in children. SIDRIA Collaborative Group, Italy (Italian Studies on Respiratory Disorders in Children and the Environment). Thorax 2000; 55: 283-8.

63. Gilliland FD, Berhane KT, Li YF, et al. Children's lung function and antioxidant vitamin, fruit, juice, and vegetable intake. Am J Epidemiol 2003; 158: 576-84.

64. Trenga CA, Koenig JQ, Williams PV. Dietary antioxidants and ozone-induced bronchial hyperresponsiveness in adults with asthma. Arch Environ Health 2001; 56: 242-9.

65. Allen S, Britton JR, Leonardi-Bee JA. Association between antioxidant vitamins and asthma outcome measures: systematic review and meta-analysis. Thorax 2009; 64: 610-9.

66. Nurmatov U, Devereux G, Sheikh A. Nutrients and foods for the primary prevention of asthma and allergy: systematic review and meta-analysis. J Allergy Clin Immunol 2011; 127: 724-33.

67. McKeever TM, Britton J. Diet and asthma. Am J Respir Crit Care Med 2004; 170: 725-9.

68. Almqvist C, Garden F, Xuan W, et al. CAPS team. Omega-3 and omega- 6 fatty acid exposure from early life does not affect atopy and asthma at age 5 years. J Allergy Clin Immunol 2007; 119: 1438-44.

69. de Vries A, Howie SE. Diet and asthma-can you change what you or your children are by changing what you eat? Pharmacol Ther 2009; 122: 78-82.

70. Kaczmarski M, Cudowska B, Sawicka-Żukowska M, Bobrus-Chociej A. Supplementation with long chain polyunsaturated fatty acids in treatment of atopic dermatitis in children. Postep Derm Alergol 2013; 30: 103-7.
71. Sydbom A, Blomberg A, Parnia S, et al. Health effects of diesel exhaust emissions. Eur Respir J 2001; 17: 733-46.

72. Bartra J, Mullol J, del Cuvillo A, et al. Air pollution and allergens. J Investig Allergol Clin Immunol 2007; 17: 3-8.

73. Bernstein JA, Alexis N, Barnes C, et al. Health effects of air pollution. J Allergy Clin Immunol 2004; 114: 1116-23.

74. Riedl M, Diaz-Sanchez D. Biology of diesel exhaust effects on respiratory function. J Allergy Clin Immunol 2005; 115: 221-8.

75. Lodovici M, Bigagli E. Oxidative stress and air pollution exposure. J Toxicol 2011; 2011: 487074.

76. Kagawa J. Health effects of diesel exhaust emissions-a mixture of air pollutants of worldwide concern. Toxicology 2002; 181-182: 349-53.

77. Pandya RJ, Solomon G, Kinner A, Balmes JR. Diesel exhaust and asthma: hypotheses and molecular mechanisms of action. Environ Health Perspect 2002; 110: 103-12.

78. Pourazar J, Mudway IS, Samet JM, et al. Diesel exhaust activates redox-sensitive transcription factors and kinases in human airways. Am J Physiol Lung Cell Mol Physiol 2005; 289: L724-30.

79. von Mutius E. Allergies, infections and the hygiene hypothesis - the epidemiological evidence. Immunobiology 2007; 212: 433-9.

80. Gerrard JW, Geddes CA, Reggin PL, et al. Serum IgE levels in white and Métis communities in Saskatchewan. Ann Allergy 1976; 37: 91-100. 